\title{
In Praise of Meliboeus: Calpurnius Siculus and Columella*
}

\author{
RUURD NAUTA
}

ABSTRACT

In discussion over the dating of the Bucolics of Calpurnius Siculus, an important role has always been played by attempts to identify the character of Meliboeus, who is to be read as a bucolic allegory of the poet's patron. By providing a new interpretation of the description of Meliboeus' literary production, I argue that he must be the agricultural writer Columella. A consideration of other aspects of Meliboeus confirms this identification, as does the analysis of a number of significant allusions to De cultu hortorum, the poem that makes up the tenth book of Columella's De re rustica. I then establish the date of Columella and discuss the consequences for dating Calpurnius, placing some parts of his book later in the reign of Nero than has been customary.

Keywords: Calpurnius Siculus; Columella; Neronian literature; pastoral; patronage

\section{INTRODUCTION}

The debate over the dating of Calpurnius Siculus, which flared up in the final decades of the twentieth century, seems to have died down in the twenty-first. The Neronian date first proposed by Sarpe in I 819 , and generally accepted since its endorsement by Haupt in I 854 , was rejected in 1978 by Champlin, who returned Calpurnius to the third century, though not to his traditional date in the time of Nemesianus. ${ }^{\mathrm{I}}$ A third-century, or at least a post-Neronian date was subsequently also argued for in contributions by Armstrong, Courtney, Baldwin and Horsfall. ${ }^{2}$ Although these later articles (unlike

\footnotetext{
* A first version of this article was presented in papers delivered at the universities of Leiden, Leeds, Ghent, Groningen and Rostock. I am grateful to my audiences for their comments, as well as to the anonymous referees and the editor of this journal, who gave very helpful guidance in shortening what was a substantially longer manuscript.

1 Sarpe I8I9: I4-46; Haupt I854= I875: 358-406; Champlin I978. Calpurnius was dated to the time of Nemesianus because he was believed to have dedicated his work ad Nemesianum. This was an error of the so-called codex Ugoleti, reproduced in the editio Parmensis of c. I492 (see Castagna I976: 48-5 I, 74-5, 2I42I; Reeve I978: 23I-3) and hence in many later editions, including Titius I590: 63; Vlitius I645: 47; Havercamp and Bruce I728: 425; Burmannus I73I: 54I. This was rejected by Wernsdorf I780: 3-27, but he stuck to a date in the late third century, as did Glaeser I 842: I-7 (who had no access to Sarpe).

2 Armstrong I986; Courtney 1987; Baldwin I995; Horsfall I997. All of these do accept Haupt's demonstration ( I 8 54: 6-I I = I 875: 366-7I) that Calpurnius' eclogues are imitated in those of Nemesianus and therefore cannot have been written later than $c .280$.
}

JRS III (202I), pp. I79-202. (C) The Author(s), 2021.

Published by Cambridge University Press on behalf of The Society for the Promotion of Roman Studies. This is an Open Access article, distributed under the terms of the Creative Commons Attribution licence (bttp:// creativecommons.org/licenses/by/4.o/), which permits unrestricted re-use, distribution, and reproduction in any medium, provided the original work is properly cited.

doi:IO.IOI7/SOO 5435821000332 
Champlin's original publication) did not receive systematic rebuttals, ${ }^{3}$ European scholarship nevertheless remained convinced of the Neronian date, and on that assumption produced a series of commentaries which by now cover all the eclogues; in a class by itself is the invaluable commentary on the entire collection by Maria Assunta Vinchesi, who in her introduction, but especially in her notes, does much to undermine the individual points made by the proponents of a later date. ${ }^{4}$ In a recent monograph on the poet, as also in two companions to 'the Neronian Age' and 'the Age of Nero', a companion to ancient pastoral, an introduction to Neronian literature and the most recent monograph on Nero himself, the Neronian date is accepted, mostly without much discussion. ${ }^{5}$ However, a recent article in this journal, proposing a late fourth-century date for another small bucolic corpus usually held to be Neronian, the Einsiedeln Eclogues, has re-asserted a late dating of Calpurnius. ${ }^{6}$ It is the aim of the present contribution to strengthen the case for a Neronian dating, not by reviewing all aspects of the debate, but by drawing attention to a Neronian poet who, in spite of the georgic character of his poem, has not yet been given his due in the study of the bucolic poems of Calpurnius. I hope to demonstrate that a consideration of Columella will shed much new light on a number of aspects of Calpurnius' work: patronage, poetics, literary technique and indeed dating. ${ }^{7}$

The Bucolica of Calpurnius Siculus consist of seven eclogues, ${ }^{8}$ of which the first, the fourth and the last are panegyrical in character. In these three, a herdsman Corydon (in I and 4 together with a brother) praises a young emperor, of whom no name is mentioned apart from 'Caesar'. In the first and fourth eclogue we also find a character called Meliboeus, who in the past has alleviated Corydon's poverty and from whom Corydon hopes to receive further support in the future, in particular recommendation of his poetry to the emperor. It is generally recognised that Corydon is a bucolic allegory for the poet and Meliboeus for his patron. ${ }^{9}$ For that reason, the discussion on dating has always been closely intertwined with attempts to identify not only the near-anonymous emperor, but also the pseudonymous patron. Before Sarpe and Haupt, he was mostly identified with Nemesianus, but when a Neronian dating was adopted, new candidates were touted. ${ }^{\text {IO }}$ Sarpe proposed Seneca, adducing his contacts with the emperor, his reputation for literary patronage and his having written both didactic works and poetry, the two kinds of literary production that Corydon ascribes to Meliboeus in $4.53-7$ (quoted below); Haupt, on the other hand, suggested that Calpurnius' name pointed to a connection with C. Calpurnius Piso, the conspirator, who was well-known for his literary patronage and his poetry (though not for didactic works). ${ }^{\text {II }}$ Since then, these two have

\footnotetext{
3 Champlin's article was countered by Townend I980; Mayer I980; Wiseman I982. Townend and Wiseman were answered by Champlin 1986, Mayer by Armstrong I986. For a systematic rebuttal of Courtney, see now Nauta 202 I.

4 Vinchesi 20I4 (on a point not dealt with by Vinchesi, see n. 66 below). Commentaries on individual eclogues or pairs of eclogues: Di Salvo I990 on 7; B. Schröder I99I on 4; Fey-Wickert 2002 on 2 and 3; Becker 20 I 2 on 5 and 6; a commentary by Beron on I is announced for $202 \mathrm{I}$.

5 Karakasis 20I6; Henderson 20I3; Littlewood 2017; Mayer 2006; Reitz 2006: II 2-I7; Drinkwater 20I9: I6I7, 267-8. On the other hand, Calpurnius is not mentioned in the section 'Nero as the Object of Contemporary Poetry' in Barrett, Fantham and Yardley 2016: 258-64.

6 Stover 2015: 3 I8.

7 Unless otherwise noted, I will quote Calpurnius from Vinchesi 2014 and Columella from Rodgers 20 IO.

8 I assume the title of the book to have been Bucolica rather than Eclogae (both are transmitted), as in the case of Virgil; see e.g. B.-J. Schröder I999: 68-70.

9 See Vinchesi 2014: 24-7. More bibliography in Karakasis 2016: 53-4, n. 27 on Corydon and 62-3, n. 77 on Meliboeus. For more on bucolic allegory, see below, Section VI.

10 The identification with Nemesianus was a logical consequence of the idea that Nemesianus was Calpurnius' dedicatee (see above, n. I). Explicit statements e.g. in Titius I 590: 70 ad I.45, 75 ad I.94; Barthius I6I3: 322 ad I.93, 356 ad 4.77; Vlitius I645: 3 I4; Burmannus I73 I: 563 ad I.94.

11 Sarpe I 8I9: 34-7; Haupt I 854: 26-7= I 875: 39I-2. Haupt also suggested (crediting Lachmann with having
} 
been the most favoured candidates, ${ }^{\mathrm{I} 2}$ but a third Neronian literary figure, the agricultural writer Columella, put forward in a Moravian Schulprogramm of 1893-4 by Franz Chytil, has received less attention. ${ }^{3}$ This is a pity, as this identification may be supported by more powerful arguments than those adduced by Chytil, and if proved correct, has important consequences.

\section{MELIBOEUS’ LITERARY PRODUCTION}

One reason that the identification with Columella has not been taken seriously is that the crucial passage on Meliboeus' literary production poses a number of problems that have not yet been satisfactorily solved. It is therefore necessary to look at this passage in some detail. Corydon is addressing Meliboeus (4.52-7):

uis hodierna tua subigatur pagina lima?

Nam tibi non tantum uenturos dicere uentos

agricolis qualemque ferat sol aureus ortum

attribuere dei, sed dulcia carmina saepe

concinis, et modo te Baccheis Musa corymbis

munerat et lauro modo pulcher obumbrat Apollo.

will you let today's page be subjected to your file? For the gods have granted you not only to tell farmers of coming winds and of what kind of rise the golden sun brings, but often you sing sweet songs, and now the Muse rewards you with Bacchic ivy-clusters, now fair Apollo shades you with laurel.

Three questions need to be addressed in interpreting this passage: (I) Does 'non tantum ... attribuere dei' refer to prose or poetry? (2) What exactly does 'qualemque ferat sol aureus ortum' mean? (3) Do the references to Apollo and Bacchus denote poetry in general or specific poetic genres?

(I) Sarpe connected 'non tantum ... attribuere dei' with Seneca's interests in natural philosophy, although he pointed out that Seneca's only surviving work on these matters, the Naturales Quaestiones, dates from after 62, which is later than the date he proposed for the fourth eclogue (58). ${ }^{\mathrm{I}} \mathrm{A}$ more fundamental objection against a reference to Seneca has been raised by Schröder (followed by Vinchesi), who argues that, as Corydon is motivating his request for criticism of his poetry, he must be appealing to Meliboeus' competence precisely in that branch of literature; this would imply an opposition between didactic poetry addressed to 'agricolae', hence in the tradition of Virgil's Georgics, on the one hand, and sweet poetry, 'dulcia carmina', on the other. ${ }^{\mathrm{I}} 5$ However, the construction with 'non tantum ... sed' may well be read in the sense that

arrived at the same idea independently) that Calpurnius was the author of the Laus Pisonis, a view that has often been accepted, but is rejected by most modern scholars, including the most recent editors of both the Laus and Calpurnius: Di Brazzano 2004: 76-82; Vinchesi 20I4: 22-3. Even if Calpurnius were the author of the Laus, it does not follow that Meliboeus must be Piso: the poet may well have solicited a further patron, especially if his suit with Piso was not successful.

12 Wiseman I982: 66 suggested the tragic poet Pomponius Secundus. Horsfall I997: I67 twice speaks of 'Meliboeus / Nero', which I fail to understand.

13 Chytil I 893-4: 3-6. To the best of my knowledge, nobody else has ever argued for this option (Bartalucci I976: 93, adduced by Karakasis 2016: 62-3, n. 77, mentions Chytil's hypothesis only to reject it). Part of the reason (apart from the near-inaccessibility of the publication) may be that Chytil's further biographical interpretations (7-9: Calpurnius was from Lucania, Iollas in 4.59 is Seneca) are unfounded.

14 Sarpe I8I9: 35-6. The terminus post quem of 62 derives from the Campanian earthquake of 62 or 63 , mentioned at 6.I.I-3; for a recent discussion, see Hine 2006: 68-72.

15 B. Schröder I99I: I I 5-I7; Vinchesi 20I4: 3 I 8. 
Meliboeus not only writes prose works (which are his main claim to fame), but also poetry (which qualifies him for the service Corydon requests from him). This would fit not only Seneca, but also Columella, the author of the twelve-book prose treatise De re rustica, of which the tenth book consists (after the preface) of a georgic poem De cultu hortorum $^{16}-$ and there is no reason why such a poem should not be called 'sweet'. ${ }^{17}$

(2) Teaching farmers about winds to come in connection with the sunrise has usually been taken as referring to weather-signs of the type treated at the end of the first book of the Georgics (352-464), where Virgil discusses 'signa' ('signs') for various types of weather (especially storms, rain and fair weather) from terrestrial and atmospheric phenomena, such as the behaviour of animals or the appearance (cloudy, reddish, etc.) of the moon and sun. However, a consideration of the phrase 'sol aureus' suggests that Calpurnius means a different type of 'signs'. The phrase occurs in a passage somewhat earlier in the first book of the Georgics $(\mathrm{I} .23 \mathrm{I}-2):{ }^{\mathrm{I} 8}$

\section{Idcirco certis dimensum partibus orbem per duodena regit mundi sol aureus astra.}

To this end the golden Sun rules his circuit, portioned out in fixed divisions, through the world's twelve constellations. ${ }^{\text {I9 }}$

'Idcirco' ('to this end') refers back to the farmer's calendar that Virgil has just expounded (I.204-3O): the regular movement of the sun through the Zodiac makes it possible to predict the weather and to know when it is time to perform the annually recurring tasks of the farmer $(1.252-3)$ :

Hinc tempestates dubio praediscere caelo possumus, hinc messisque diem tempusque serendi.

Hence, though the sky be fitful, we can foretell the weather's changes, hence the harvest tide and sowing time.

The method by which this is done is to observe the risings and settings of the stars: 'nec frustra signorum obitus speculamur et ortus' ('not in vain do we watch the signs, as they rise and set', I.257), either immediately after sun-down ('evening rising / setting') or and this is the default option - just before sun-rise ('morning rising / setting' or 'rising / setting' tout court), which accounts for the close connection of the sun, and especially the sun-rise, with the observation of the stars. ${ }^{20}$ The stars too are 'weather signs', not based on contingent terrestrial or atmospheric events, but on yearly recurring astronomical phenomena; the first type we may call, with Daryn Lehoux, 'Theophrastan' (after Theophrastus, to whom the oldest extant systematic treatment of this type of sign is attributed), the second 'astrometeorological'. ${ }^{2 \mathrm{I}}$ It may well be to this

\footnotetext{
16 The title De cultu hortorum is given in the table of contents at the end of Book I I (which stems from Columella himself: II.3.65) and also at 9.I6.2, IO.pr.I, 3, I I.I.I and in the first and last lines of the poem itself (see $\mathrm{n} .62$ below). In the explicit of the book, the manuscripts give its title as Cepuricus de cultu hortorum, which could well

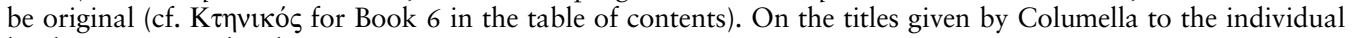
books, see B.-J. Schröder I999: 26-7.

17 For the word dulcis (or suauis) as applied to didactic poetry, see Lucr. I.924-5, I.938 = 4.I3, I.947 = 4.22; Verg., G. 2.475-89, 3.29 I-2. Manilius, however, warns his addressee not to expect 'dulcia carmina' (3.38).

18 Other occurrences of the expression: Enn., Ann. 92 (quoted Cic., Div. I. Io8); Ov., Met. 7.663; Apul., Met. I I.7.2 (all of the rising sun; cf. Catull. 63.39; Lucr. 5.46I-2); Verg., G. 4.5 I (on summer succeeding winter). Likewise in connection with the Zodiac: Avien., Arat. I053 (cf. 66I-2), Auson., Ecl. 8.7, I 5, 25.5 Green.

19 This and the following two translations are taken from Fairclough and Goold I999.

20 For a brief explication, see Mynors I990: 46-7.

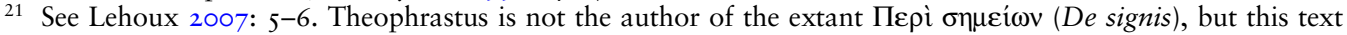
may well derive, at one or more removes, from his work of that title; see Sider and Brunschön 2007: 40-3.
} 
second type of signs that Calpurnius refers with his expression 'qualemque ferat sol aureus ortum', which would then mean 'and in what sign of the Zodiac the golden sun rises'.

Of the three Neronian candidates for the identity of Meliboeus, neither Piso nor Seneca wrote, as far as we know, on astrometeorology (or on Theophrastan signs, for that matter), but Columella did, and at length, in the second chapter of the eleventh book of De re rustica. $^{22}$ Here, Columella combines a chronological survey of the bailiff's duties throughout the year with an astrometeorological parapegma, i.e. a scheme linking calendar dates to astronomical phenomena and the weather which concurs with these phenomena. $^{23}$ Literary astrometeorological parapegmata are known, in various guises, from a number of Greek and Latin works (most notably Geminus' Eisagogē, Ovid's Fasti, Pliny's Natural History and Ptolemy's Phaseis), but Columella's is conspicuous for the combination of two features: the great amount of attention given to winds ${ }^{24}$ and the use of the sun's movements through the Zodiac, in addition to the stellar phases, as astronomical markers of time. Columella always mentions the day on which the sun passes into a new sign of the Zodiac, noting the weather, and most often the winds, which are then to be expected. I quote the first three instances (II.2.4, 20, $3 \mathrm{I}):^{25}$

XVII Kal. Febr. Sol in Aquarium transit, ... Africus, interdum Auster cum pluuia.

XV Kal. Mart. Sol in Pisces transitum facit, nonnumquam uentosa tempestas.

XVI Kal. Apr. Sol in Arietem transitum facit, Fauonius uel Corus.

I6 January: The sun passes into Aquarius ... south-west wind, sometimes south wind with rain.

I 5 February: The sun passes into Pisces, sometimes windy weather.

I7 March: The sun passes into Aries, west or north-west wind.

Thus, it seems quite possible that Calpurnius' phrase on teaching farmers about winds and the rise of the golden sun refers to Columella's De re rustica. ${ }^{26}$

(3) It has frequently been assumed that Bacchus' ivy - for that plant is indicated by 'corymbis' - refers to tragedy and Apollo's laurel to lyric, and this has been enthusiastically embraced by proponents both of Seneca and Piso, as the former is the author of tragedies (though not, as far as we know, of lyric poetry outside the choral odes in these tragedies), whereas the latter performed as a tragic singer and is credited with poetry as well as proficiency on the lyre. ${ }^{27}$ However, Schröder in his commentary has shown that the combination of Bacchus and Apollo quite often refers to other genres or to poetry in general; ${ }^{28}$ he does not, however, adduce a passage that, assuming

\footnotetext{
22 It may be noted that, unlike Columella, neither Seneca nor Piso is mentioned in the first book of Pliny's Natural History among the sources for Book I8, where among other agricultural topics both astrometeorological and Theophrastan signs are treated.

23 On parapegmata, see Lehoux 2007, who provides texts (apart from Ovid, Columella and Pliny) and translations of all surviving parapegmata (literary and inscriptional, astrometeorological and of other types).

24 Cf. also I.pr.22: the farmer should know the risings and settings of the stars 'ne imbribus uentisque imminentibus opera inchoet' ('that he may not begin his operations when rains and winds are threatening'), 32 'in motibus astrorum uentorumque Metonis prouidentiam uel Eudoxi' ('the foreknowledge of Meton or Eudoxus with respect to the movements of the stars and winds').

${ }_{25}$ Winds are also mentioned when the sun passes into Cancer (49), Leo (52), Virgo (58), Sagittarius (88) and Capricorn (94).

26 Columella had earlier written a work 'aduersus astrologos' (conceivably the title; cf. Sextus Empiricus' Пpòs

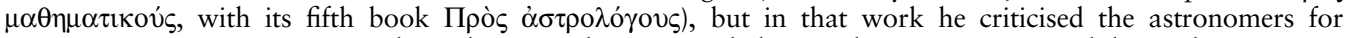
asserting too strict a correspondence between the stars and the weather (II.I.3 I). He did not there instruct farmers, as he does here (II.I.32 'in hac autem ruris disciplina'; cf. 9.I4.I2, II.2.2), so it is not likely to be the work to which Calpurnius refers.

27 Piso's tragic performances are mentioned in Tac., Ann. I 5.65 and the scholium from 'Probus' on Juv. 5. I09, his 'carmina' as well as playing on the lyre in Laus Pisonis I 63-77.

28 B. Schröder I99 I: I I 8, mentioning Prop. 3.2.9; [Tib.] 3.4.44; Ov., Am. I.3.I I; Stat., Silv. 5.I.26; Juv. 7.64;
} 
a Neronian date for Calpurnius, would be nearly contemporary. Lucan in his proem addresses Nero (1.63-6):

nec, si te pectore uates

accipio, Cirrhaea uelim secreta mouentem

sollicitare deum Bacchumque auertere Nysa:

tu satis ad uires Romana in carmina dandas.

nor, if I as bard receive you in my breast, would I wish to trouble the god who reveals the secrets of Cirrha [i.e. Delphi] or turn Bacchus away from Nysa: you are sufficient to give me force for Roman songs.

The implication is that if Nero had not inspired Lucan's epic on the Roman civil wars, the poet would be dependent on the default deities, that is to say Apollo and Bacchus. If these gods can inspire historical epic, they may just as well inspire didactic epic in the tradition of Virgil's Georgics. Indeed, in the Georgics, both Apollo and Bacchus are invoked, though not simultaneously, partly as gods suiting the subject-matter (Bacchus viticulture and Apollo, as Apollo Nomios, care of the flocks), partly in a more general capacity. ${ }^{29}$ Calpurnius' wording, therefore, would very well suit Columella's De cultu hortorum.

It is possible to go further, and argue that Calpurnius must refer to Columella's poem, because he unmistakably alludes to a central meta-poetical passage there. I give again Corydon's characterisation of Meliboeus' poetry (Calp. 4.55-7):

sed dulcia carmina saepe

concinis, et modo te Baccheis Musa corymbis

munerat et lauro modo pulcher obumbrat Apollo.

These lines evoke Columella's description of the cinara, probably an ancestor of the modern artichoke (IO.235-4I): ${ }^{30}$
Hispida ponatur cinara, quae dulcis Iaccho
potanti ueniet nec Phoebo grata canenti;
haec modo purpureo surgit glomerata corymbo,
murteolo modo crine uiret deflexaque collo
nunc adaperta manet, nunc pinea uertice pungit,
nunc similis calatho spinisque minantibus horret,
pallida nonnumquam tortos imitatur acanthos.

The shaggy cinara should be planted, which will be sweet to Iacchus [= Bacchus] when he drinks, but not welcome to Phoebus [= Apollo] when he sings; this now rises in a dense mass, like a purple ivy-cluster, now is verdant with myrtle-coloured leaves, and, with neck bent down, now remains wide open, now pricks with its cusp like a pine-cone, now looks like a basket and bristles with threatening thorns, and sometimes, pale, imitates twisted acanthuses.

This passage has been recognised as Columella's central poetological statement by Évelyne Prioux. ${ }^{3 \mathrm{I}}$ She points out that the ivy and the acanthus (and one may add the myrtle) are precisely the plants that Virgil says he would have dealt with, had he not decided to forego the topic of horticulture: 'nec ... flexi tacuissem uimen acanthi / pallentisque

add also (apart from Lucan, quoted in the text) Ov., Ars am. 3.347-8; [Verg.] Catal. 9.59-60; Stat., Silv. I.2.I7, 220-4, I.4.I9-2 I, I.5.3, 2.7.7-8, 5.3.5-6.

29 Verg., G. I.7, 2.I 8 (Bacchus as god of the vine), 3.2 (Apollo Nomios), 4.8 (Apollo as god of poetry).

30 On the botanical identification of the plant, see Boldrer I996: 259, with references. For the echo of 'Apollo' in 'collo' I am indebted to one of the anonymous referees.

31 Prioux 2013: 29-40. 
hederas et amantes litora myrtos' ('nor should I have passed in silence ... the twining tendril of the acanthus, pale ivy sprays, or the shore-loving myrtle', G. 4.I22-4).32 Moreover, the ivy and the acanthus frame the famous metapoetical bowl in Theocritus' first idyll (29-3 I, 55), as well as the metapoetical cups in Virgil's third eclogue $(39,45)$. Finally, whereas the Bacchic ivy is in any case a poetical weed, the acanthus, she argues,

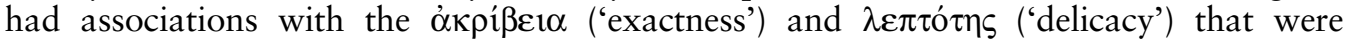
among the leading ideals of Hellenistic poetry. Prioux does not, however, discuss the references to Bacchus and Apollo, although they link this passage to an elaborate recusatio which immediately precedes. Here, after a high-flown description of the spring as a season of fertility throughout the cosmos (I96-2I4), Columella calls himself back to his more modest subject-matter and the style appropriate to it (215-29; my translation tries to reproduce the convoluted syntax expressive of the poet's rapture): ${ }^{33}$

2 I 5 Sed quid ego infreno uolitare per aethera cursu passus equos audax sublimi tramite raptor? Ista canit, maiore deo quem Delphica laurus inpulit ad rerum causas et sacra mouentem orgia naturae secretaque foedera caeli

220 extimulat uatem per Dindyma casta Cybeles ${ }^{34}$ perque Cithaeronem, Nyseia per iuga Bacchi, per sua Parnasi, per amica silentia Musis Pierii nemoris, Bacchea uoce frementem 'Delie te Paean' et 'te Euhie Euhie Paean'.

225 Me mea Calliope cura leuiore uagantem iam reuocat paruoque iubet decurrere gyro et secum gracili conectere carmina filo quae canat inter opus Musa modulante putator pendulus arbustis, holitor uiridantibus hortis.

But why have I let my horses fly about through the sky in unbridled course, boldly, carried away on a lofty path? These things are sung by a poet whom with the force of a greater god a Delphic laurel has impelled towards the causes of things and, as he reveals the holy mysteries of nature and the secret laws of heaven, spurs on, him the bard, over the chaste Dindyma mountains sacred to Cybele, and over Cithaeron, over the ridges of Nysa, sacred to Bacchus, over those of its own Parnassus, through the silence, friend to the Muses, of the Pierian wood, as he shrieks with Bacchic voice 'You, Delian Paean' and 'You, Euhius Euhius Paean'. As for me, as I wander with lighter care, ${ }^{35}$ my Calliope already calls me back and commands me to ride in a small circle and, with her, to weave songs from a slender thread, such as amid his work, accompanied by the Muse, the pruner may sing, hanging in the trees, or the vegetable grower in the verdant gardens.

\footnotetext{
32 Tr. Fairclough and Goold I999. The word 'pallida', though used by Columella of the acanthus rather than the ivy, may underline the imitation, to which (as suggested by F. Klein ap. Prioux 20I3: n. 75) the word 'imitatur' may draw attention.

33 On this passage as a recusatio, see, apart from the commentary in Boldrer I996, Prioux 2013: 24-8. The language ('sacra mouentem ... secreta ...uatem ... Nyseia ... Bacchi') recalls Luc. I.63-5, quoted above, which probably was written at about the same time; see below, Sections V and VI, for dating.

34 Rodgers reads castra with some of the manuscripts and Cybebes with Postgate, but see Boldrer I996: 248 for casta and Hall I969: 206 on Claud., Rapt. Pros. I.2I 2 for Cybēles.

35 'Cura leuiore' must refer to the 'lighter' kind of poetry to which Columella is recalled, and 'uagantem' to his being carried away from it (taking up 'raptor'), but it is difficult to get this out of the Latin. Possibly the opposition is insufficiently expressed ("“uagantem", although my "cura" should be "leuior"'); alternatively, perhaps 'cura leuiore' is to be separated from 'uagantem' ('as I wander, my Calliope calls me back with (i.e. reminds me of) my "cura leuior"'). For other attempted solutions, see Boldrer I996: 252.
} 
Columella states that sublime poetry on the mysteries of the cosmos belongs to poets who are inspired both by Apollo (represented by the Delphic laurel and Parnassus) and by Bacchus (represented by Cithaeron and Nysa) - such poets as sing 'with Bacchic voice' of a Dionysiac Apollo ('Euhie Euhie Paean', if the text is sound). Columella, however, should write a 'slender', Hellenistic kind of poetry, fitting his rustic subject-matter. This is then immediately put into practice, with instructions for planting such prosaic plants as cress, cucumber and pumpkin (230-4), and, as a climax, the cinara, which does have links to Apollo and Bacchus, but in a more down-to-earth manner: it is pleasant for drinkers, but not for singers (presumably because its consumption roughens the throat). ${ }^{36}$ Calpurnius' Corydon, therefore, praises his patron Meliboeus' poetry in terms that not only fit Columella, but allude specifically to the passage in Columella where he programmatically defines his own poetry. ${ }^{37}$ I conclude that Meliboeus is Columella.

\section{FURTHER ASPECTS OF MELIBOEUS}

If this argument is correct, the other characteristics of Meliboeus to be found in Calpurnius' eclogues should also apply to Columella. These may be subsumed under three headings: (I) Meliboeus' religious veneration of Virgil; (2) his association with the province of Baetica; (3) his access to the emperor.

(I) When Corydon announces his intention to play on the shepherd's pipe that had once belonged to Tityrus, in other words to write bucolic poetry in imitation of Virgil, Meliboeus warns him that he attempts great things if he strives to be Tityrus ('Magna petis, Corydon, si Tityrus esse laboras', 4.64), because Tityrus was a 'holy bard' ('uates sacer', 65). Corydon immediately agrees: 'Est, fateor, Meliboee, deus' ('He is, I admit, Meliboeus, a god', 70). There are only very few passages before Late Antiquity where Virgil (or his poetry or his inspiration) is called divine, ${ }^{38}$ and none at all where he is straightforwardly called a god. Nonetheless, it is precisely in Columella that we find the closest parallels for Calpurnius' language. In the prose preface to Book Io, Columella explains that he has given in to the repeated urgings of his addressee Silvinus to write this book in verse, because Virgil himself in the Georgics has left the topic of horticulture for others after him to treat. ${ }^{39} \mathrm{He}$ therefore undertakes to fill this lacuna 'according to the wish of the most venerable bard' ('ex uoluntate uatis maxime uenerandi', ro.pr.3) and even 'inspired, as it were, by his godhead' ('cuius quasi numine instigante', Io.pr.4); at the very end of the poem he again mentions 'the instructions of the celestial bard Maro' ('siderei uatis ... praecepta Maronis', 434).$^{40}$ In the execution of his task, Columella borrows extensively from Virgil, most of all of course from the Georgics, but he also imitates other poets, particularly Ovid. ${ }^{4 \mathrm{I}}$ It also fits Columella, therefore, that Meliboeus, when praising the songs of Corydon and his brother, declares that he would not prefer the nectar sipped by Pelignian swarms ('ut non ego malim / quod Peligna solent examina lambere nectar', 4.I 50-I), in other words the poetry of Ovid.

\footnotetext{
36 See Boldrer I996: 259-60.

37 It may be noted that such an allusion would be beyond any imaginable powers of a third-century poet posing as a Neronian one, as postulated by Horsfall I997. Such a poet would need to have (I) thought of casting Meliboeus as Columella, (2) identified Columella's central poetological passage, and (3) made Corydon, in praising Meliboeus' poetry, imitate that passage.

38 Sen., Brev. 9.2 'uelut diuino ore instinctus'; Stat., Theb. I2.8 I6 'diuinam Aeneida'; [Verg.] Catal. I 5.3 (of uncertain date) 'diuini ... poetae'; one may also compare Silius Italicus venerating Virgil's tomb 'ut templum' (Plin., Ep. 3.7.8). In the Virgil scholarship of Late Antiquity, see e.g. DServ. ad Aen. 3.349 and 463 ; Tib. Cl. Don. ad Aen. 2.5 I0; Macr., Sat. 5.13.5.

39 Columella refers to Verg., G. 4.I 47-8, which he again quotes at the very beginning of his poem (5).

40 These passages were already adduced by Chytil I $893-4: 5$.

41 On Columella and earlier poetry, see Boldrer I996: I 5-26, and specifically on Ovid Prioux 20I3: 9-2 I, $26,28$. For Calpurnius' own debt to Ovid, see Fucecchi 2009.
} 
(2) Earlier in the fourth eclogue, Corydon thanks Meliboeus for his support, which has enabled him to enjoy the bucolic life much like Tityrus in Virgil's first eclogue (37-42):
per te secura saturi recubamus in umbra
et fruimur siluis Amaryllidos, ultima nuper
litora terrarum, nisi tu, Meliboee, fuisses,
ultima uisuri, trucibusque obnoxia Mauris
pascua Geryonis, liquidis ubi cursibus ingens
dicitur occiduas impellere Baetis harenas.

Because of you I recline well-fed in the carefree shade and enjoy the woods of Amaryllis, I who but recently was destined to see the furthest coasts of the earth - if you had not been, Meliboeus - yes, the furthest, and the pastures of Geryon exposed to the savage Mauri, where with clear currents the mighty Baetis is said to strike against the western sands.

The reference here is unequivocally to Gades (modern Cádiz), for that is where the monster Geryon was believed to have herded his cattle (which was then driven off by Hercules). ${ }^{42}$ Now Gades was the patria of Columella, ${ }^{43}$ and Corydon might therefore be considered to be rather untactful in describing the region in such negative terms. But this is functional for his expression of gratitude to his patron for not having sent him there, an option that had apparently been under consideration. ${ }^{44}$

(3) At the end of Calpurnius' first eclogue, Corydon and his brother Ornytus express the hope that Meliboeus will bring their songs to the attention of the emperor, i.e. (if Meliboeus is Columella) Nero: 'forsitan Augustas feret haec Meliboeus ad aures' (I.94). And towards the end of the fourth eclogue, Corydon makes the request explicit (I 58-9):

fer, Meliboee, deo mea carmina: nam tibi fas est sacra Palatini penetralia uisere Phoebi.

bring, Meliboeus, my songs to the god: for you are allowed to see the holy inner shrine of Palatine Phoebus.

The analogy with the first eclogue shows that 'the god' is here the emperor, and the sentence with 'nam' ('for') must give the reason why Corydon feels able to make the request: Meliboeus has access to this divine personage. ${ }^{45}$ The precise formulation, however, is complicated: 'Palatine Phoebus' must in the first instance refer to the Temple of Apollo on the Palatine; to that temple a public library was attached, and it has been thought that Calpurnius asks for admission of his work there. ${ }^{46}$ Yet the religious language and the stress on privileged access do not fit the library, and it is more likely that the 'holy inner shrine' refers to the house of Nero, which until the great fire of 64 and the subsequent construction of the Domus Aurea was part of the same group of buildings as the Temple of Apollo. ${ }^{47}$ On this

\footnotetext{
42 The sources sometimes locate Geryon more precisely on the island of Erythea (now no longer an island), where the city of Gades was first founded: thus Plin., HN 4.I I9-20; further references in B. Schröder I99 I: I06. It is no objection that Gades, although situated on the Ocean opposite Mauretania ('trucibus ... obnoxia Mauris'), is not exactly at the mouth of the Baetis; cf. Sil. 16.194-7.

43 Col. 8.I6.4, I0.I 85 .

44 The gist of this argument already in Chytil s 893-4: 5-6.

45 'Deus' is repeatedly used of the emperor earlier in the poem ( $7,30,144)$, and the strophes sung in praise of 'Caesar' (82-146) find ever new variations of celebrating his numinous power, so that the sacralisation in these lines is not unexpected.

46 Horsfall I993: 62, who unknowingly revived the interpretation of Wernsdorf I780: I33 (rejected by Sarpe I8I9: I7).

47 The precise development of the imperial dwellings on the Palatine before 64 is much contested (see Wiseman 2013 and now Wiseman 2019), but the controversy does not affect my argument. The house of Augustus formed a unity with the temple, according to Ov., Fast. 4.95 I-4; Met. I 5.864-5.
} 
interpretation, the expression 'Palatine Apollo' assumes a secondary reference to Nero himself, in whose self-representation Apollo played a prominent part. ${ }^{48}$

While Columella does not in his work display any personal familiarity with Nero, a case can be made that Calpurnius' hope of brokerage was not unrealistic. Among the 'leaders of our state' ('ciuitatis nostrae principes') with whom, in the very first words of his treatise, Columella claims to converse 'frequently' ('saepenumero'), a few are mentioned by name. Seneca is praised as 'a man of outstanding talent and learning' ('uir excellentis ingenii atque doctrinae', 3.3.3), but this does not prove personal acquaintance. We are on firmer ground with 'my friend Gallio' ('Gallioni nostro', 9.16.2), who encouraged Columella to write his tenth book in verse, and who is doubtless to be identified with Seneca's brother Iunius Gallio, who was suffect consul in $56 .{ }^{49}$ Another of Columella's friends is ' $M$. Trebellius noster' (5.I.2), who must be the M. Trebellius who was commander of the legion in which Columella served as a military tribune in 36 , and is quite likely to be the M. Trebellius who was suffect consul together with Seneca in $55 .^{\circ}$ Finally, according to the subscription of Book II, Columella wrote a book on arboriculture dedicated to Eprius Marcelllus (suff. 62), who was an amicus of Nero and highly influential in the later part of the reign..$^{\text {I }}$ So, even if we cannot prove that that Columella had direct access to the emperor, we at least know that he moved in the circles of those who did.

\section{FURTHER HOMAGES TO COLUMELLA}

If Meliboeus is Calpurnius' patron Columella and if Calpurnius pays homage to the latter's poem on gardens, one would expect that Calpurnius would also allude to that poem in other significant passages of his work, and this is indeed what we do find. To begin with, in the very first lines of his book, Calpurnius apparently alludes to nearly the last lines of Columella's. In Calpurnius' first eclogue, Corydon starts out, in a manner unparalleled in ancient bucolic, with an elaborate poetical paraphrase of the time of year $(\mathrm{I} . \mathrm{I}-3):{ }^{52}$

Nondum Solis equos declinis mitigat aestas, quamuis et madidis incumbant prela racemis et spument rauco feruentia musta susurro.

Not yet does the waning summer alleviate the heat of the Sun's horses, although the wine-presses weigh upon the juicy grape-clusters and the seething must foams with hoarse whispering.

Neither spumare nor feruere is a surprising verb to use of mustum, ${ }^{53}$ but there is only one other passage in Latin verse where all three terms occur together, ${ }^{54}$ and this is in the brief hymn to Bacchus which concludes Columella's poem before the four-line epilogue (43I-2):

\footnotetext{
48 One may compare Palatinus Tonans in Martial (9.39.I, 86.7), referring to Domitian. On Nero and Apollo, see further below, Section VI.

49 On the consuls of 55 and 56, see Camodeca 1986.

50 Columella's tribunate is attested in CIL 9.235 = ILS 2923; Cichorius I922: 4I7-2I made the identification of the commander with Seneca's colleague. On M. Trebellius, see further Birley 2005: 52-6.

51 See Tac., Hist. 4.7-8 (4.8.3 amicitia with Nero); Ann. 16.22.6-33.2.

52 On the lack of parallels for this opening, see below, Section VI. On the relationship of this passage to Sen., Apoc. 2.I, see below, n. 87 .

53 For spumare Vinchesi 20I4: I03 adduces Verg., G. 2.6; Prop. 3.I7.I7; Aetna 267; and (with the compound 'despumant') Manil. 3.663, but note that the reading 'spument' in Propertius and the Aetna is a conjecture based precisely on analogy with our passage. Feruere is regularly said of mustum in prose, but in verse there is only Ov., Tr. 3.10.72 'nec cumulant altos feruida musta lacus', which may have been an influence on either or both of our passages ('feruentia musta' in Calp., 'ferueat ut lacus ... musto' in Col.).

54 In prose the three terms occur together in Plin., HN II.32 (honey compared to must); Fronto, M. Caes. 4.4.3 (Marcus Aurelius comparing his love for Fronto to fermenting and foaming must); and Ambrose, De uiduis 5.28.
} 
ferueat ut lacus et $\nmid$ musto $\dagger^{55}$ completa Falerno

exundent pingui spumantia dolia musto.

that the vat may seethe and the jars, full with much (?) Falernian, may overflow, foaming with thick must.

Although the imitation could conceivably be in the other direction, it is more likely that the client pays homage to the patron rather than the other way around. If so, Calpurnius would begin where Columella had ended, and thus inscribe this eclogue, but also the entire collection which it opens, in the tradition of Columella's different, but also related, rustic poetry.

An even more significant reference to Columella's closural gestures is to be found in the second eclogue. This poem presents an amoebaean singing match between Idas, a shepherd, and Astacus, a gardener, and in featuring the latter already pays homage to Columella by introducing the subject matter of his didactic poem into the genre of bucolic. ${ }^{56}$ The blending of one genre with another is reflected at the thematic level by Astacus' insistence on his competence in grafting (40-4), in response to his opponent's boasts about cross-breeding sheep of different colours (36-9). ${ }^{57}$ Astacus' lines recall a passage in Columella, where he invokes the help of the Muses for a poem dealing with, among other things, grafting (I0.35-4O), although he does not in fact treat that topic in what follows. ${ }^{5}$ This suggests that Columella may have introduced the motif for its metapoetic potential, drawing attention to his 'grafting' of poetry onto prose and of horticulture onto standard georgic material. ${ }^{59}$ That Calpurnius read Columella in this way, and intended a similar reflection of his own practice of generic 'grafting', is confirmed by the motif of 'sources' in the preceding pair of strophes.

In these strophes, which open the song contest, the shepherd Idas claims poetic initiation by the god Silvanus, whereas the gardener Astacus selects deities that are specifically connected with horticulture: Flora, the goddess of flowers, Pomona, the goddess of fruits, and finally the Nymphs, who once said to him: 'accipe ... puer, accipe fontes: / iam potes irriguos nutrire canalibus hortos' ('take from us, ... boy, take from us these sources: now you can feed your garden by irrigating it through channels', 2.34-5). Although Astacus is not invited to drink from the water, the initiatory context, in which he is garlanded by Flora (32) and receives the sources from the Nymphs (who traditionally inspire bucolic poetry and also inspire Columella's poem on horticulture), guarantees that the 'sources' here are sources of poetic and generic inspiration. ${ }^{60}$ It is with this meaning that they recur at the end of the eclogue, at least if the allusion there

\footnotetext{
55 'Musto' seems to have crept up from the following line. Rodgers prints 'mixto', which was proposed by Boldrer I996, but later withdrawn by her in favour of 'fusco' (Boldrer 2000). I translate the vulgate 'multo' (from the Aldine and one late manuscript; see Boldrer 2000: 246-8).

56 This was already suggested by Chytil I 893-4: 6. Later scholars, beginning with Kettemann I977: I00-7, have seen the georgic elements in Astacus' strophes, but have neglected the circumstance that these are specifically concerned with horticulture, a subject notoriously passed over by Virgil, but taken up by Columella. For most of the parallels that Kettemann adduces from the Georgics, better ones from Col. Io may be given; I mention only 48-5I Col. IO.I 52-4, both on the watering of transplanted shoots ('mutata ... plantaria terra', $5 \mathrm{I} \sim$ 'planta / ... mutata loco', I 53-4) when these are placed in a dry 'area' (49 I 52 ).

57 For the metapoetical resonances of these lines, see Karakasis 2016: 204-6.

58 The omission was made good a few centuries later by Palladius, who added a supplement in verse to his prose treatise on agriculture to deal with a topic omitted by Columella, just as Columella's supplementary poetic book dealt with a topic omitted by Virgil.

59 This passage is linked to that in Calpurnius and both are interpreted metapoetically by Lowe 20 I0: $477-9$.

60 For poetic initiation involving both garlanding and sources, see Lucr. I.927-30 = 4.2-5 (perhaps from Ennius); Hor., Carm. I.26.6-9; Prop. 3.I.I-6, I9-20. For Nymphs as inspiring bucolic poetry, see Theocr. 7.9 I-3 (cf. also I48); Verg., Buc. IO.I (the Nymph and spring Arethusa; cf. Theocr. I.I I7 and [Mosch.] 3.IO, 77); and especially Calpurnius' main model in this eclogue, Verg., Buc. 7, where the song contest starts with an invocation of the 'Nymphae ... Libethrides' (2I), on which DServius notes, among other explanations, 'a fonte Boeotiae', and
} 
to Columella is recognised. ${ }^{61}$ Evening is falling (93), and it is therefore time to end bucolic song; both singers give instructions to their servants, Idas to drive home the flocks, Astacus to water the garden $(96-7)$ :

\section{I procul, i, Doryla, primumque reclude canalem}

et sine iam dudum sitientes irriget hortos.

Go off, go, Dorylas, and open up the first channel, and let it irrigate the garden that has been thirsting for a while now.

The repeated 'I ... i' recalls the repeated 'Ite ... ite' at the end of Virgil's book of Bucolics: 'Ite domum saturae, uenit Hesperus, ite capellae' ('Go home full-fed, the Evening Star is coming, go, my goats', I0.77). But a more specific reference is made to the end of Virgil's third eclogue, of which the final line is 'Claudite iam riuos, pueri: sat prata biberunt' ('Now close the channels, boys: the meadows have drunk their fill', 3.III). Calpurnius, however, reverses Virgil's closural gesture: the fields are thirsting ('sitientes') rather than having drunk their fill ('sat'; cf. 'saturae'), and the channels are not closed ('claudite'), but opened ('reclude'). It is Columella who helps to solve the paradox of this reversal.

When Columella's poem, which started with the autumn and followed the course of the year, has come full circle and reached the time of the vintage again, the god Bacchus himself exhorts the poet that it is time to make an end of it: '... Euhios excultosque iubet claudamus ut hortos' ('... Euhios [i.e. Bacchus], and he orders that we close the gardens we have cultivated', 424), and the poet immediately heeds the instruction: 'Claudimus' ('We close them', 425). But this is not quite the end: the poet continues with the brief description of a vintage festival that was quoted above, and then adds an epilogue (433-6):

Hactenus hortorum ${ }^{62}$ cultus, Siluine, docebam

siderei uatis referens praecepta Maronis,

qui primus ueteres ausus recludere fontis

Ascraeum cecinit Romana per oppida carmen.

Thus far I taught the cultivation of gardens, Silvinus, recalling the precepts of the heavenly bard Maro, who first, having dared to open up ancient sources, sang an Ascraean [i.e. Hesiodic] song in Roman towns.

The final two lines characterise Virgil as the author of the Georgics in words that he had used himself (G. 2.174-6):

tibi [scil. Saturniae telluri] res antiquae laudis et artem ingredior sanctos ausus recludere fontis

Ascraeumque cano Romana per oppida carmen.

for you [scil. Italy] I undertake a matter and art praised in days of old, having dared to open up holy sources, and I sing an Ascraean [i.e. Hesiodic] song in Roman towns.

Servius 'Libethros fons est, ubi coluntur Musae'. In Col. Io, the Nymphs, 'Pegasidum comites' (263) are invoked (263-8I), as well as the Muses themselves (40, 225-9).

61 'Fontes' are mentioned by Astacus throughout the eclogue: after 34-6 and before 96-7 they appear also at 48$5 \mathrm{I}, 57-8,88-9$. Although there is no obvious metapoetical allegory in these intermediate passages, they do keep up the association of Astacus' song with the 'fontes' provided by the Muses.

62 With Boldrer I996: 354 I read hortorum with the second hand in S and some late manuscripts, which produces a perfect ring composition with the first verse 'Hortorum quoque te cultus, Siluine, docebo'. Rodgers retains agrorum of the major manuscripts. 
Columella, in citing Virgil's claim to have opened up the sources of Hesiodic inspiration for Roman poetry, adds the word 'primus' (435), stressing that Virgil was the 'first' to do so. By characterising Virgil in this way in the last lines of his book, he clearly means to claim that he himself is the first to have opened up, in his turn, the sources of Virgilian inspiration for a georgic poem on horticulture. And just as clearly, Calpurnius' 'primum... reclude canalem' marks the next step in the generic progression: Calpurnius, in his turn, is the first to open up the sources of Columellan inspiration for a novel kind of bucolic poem.

Another Calpurnian eclogue which may contain homage to Columella is the fifth, which consists of a long list of precepts ('praecepta', 3) on the care of sheep and goats, given by an old shepherd to his son or foster-son ('alumno', 3). The didactic character of the poetry might in itself honour Columella's poetic Book Io, and the subject-matter might be inspired by its treatment in one of Columella's prose books $(7.2-7))^{63}$ The main source, however, is Virgil, Georgics 3.284-473, and Columella's discussion does not seem to have been used. ${ }^{64}$ Nor does this poem include any unequivocal cases of imitation of $D e$ cultu hortorum. ${ }^{65}$ It will therefore be safest to consider dependence of the fifth eclogue on Columella as no more than possible.

In summary: Calpurnius alludes to Columella's poetic Book Io at the beginning of the first eclogue and hence of the book of Bucolica, in the second and fourth eclogues and possibly in the fifth, while the fourth eclogue also has a laudatory reference to the subject matter of Book II. These conclusions are pertinent to the question of dating with which I began, and to which I now return.

\section{DATING COLUMELLA}

If, as I have argued, Calpurnius in various ways pays homage to his patron Columella, then his date is in any case Neronian. ${ }^{66}$ But a more exact dating within the Neronian period will depend on the dates we assign to the writings of Columella to which he alludes. The terminus ante quem of the De re rustica (or at least Book 3 ) is the death of Seneca in 65 , as Columella speaks in the present tense of the famous Nomentan vineyard 'quam possidet Seneca, uir excellentis ingenii atque doctrinae' ('that is owned by Seneca, a man of outstanding intellect and learning', 3.3.3). This property is mentioned by Seneca himself in letters dating from 64, and must have been a rather recent acquisition. ${ }^{67}$

63 Chytil I 893-4: 6 mentions only the latter aspect.

64 Becker's claim (2012: 30) that Calpurnius shows 'bis ins Detail reichende strukturelle und motivische Gemeinsamkeiten' with Columella, is misleading: everything Calpurnius has in common with Columella derives from Virgil, with the one exception of the recommendation of burning hart's horn to repel snakes (Calp. 5.90; Col. 7.4.6), but this is widely paralleled, as shown by Vinchesi: 20I4: 4I4-I5, both in agricultural writers (Varro, Rust. 3.9.I4; Plin., HN 8.II8, I0.I95, 28.I49) and in non-technical authors (Luc. 9.92 I; Mart. I 2.28 (29).5), and thus need not derive from Columella.

65 The most promising instance is 'nidosque reuersa lutabit hirundo' (Calp. 5.I7) 'ueris et aduentum nidis cantabit hirundo' (Col. Io.80).

66 One feature often used in denying a Neronian date to Calpurnius merits a footnote here: the correption or production of final -o (outside of datives and ablatives). Horsfall, basing himself on Armstrong I986: I29-35, writes: 'If we compare the usage of CS with that of the roughly contemporary (on a Hauptian view!) Columella Io, Persius, Seneca, Lucan and Petronius we find him extremely cautious and "reactionary" by comparison' (I77). But for Columella (who was not considered by Armstrong) this is not true. Calpurnius correpts only the common ego, modo and puto, and produces (si)quando, subito and a number of first-person verb forms (Hartenberger I9II: 68; Armstrong I986: I34 is incomplete); Columella likewise correpts only ego and modo and produces Rubigo and the first-person verb form moneo (Hartenberger I9I I: 73; add principio (6) and idcirco (I26)). Calpurnius has more first-person verb forms, because of the dialogical character of his poems, but otherwise his practice matches Columella's.

67 Sen., Ep. I04.I, I IO.I; cf. the references to himself as a winegrower in Ep. I I 2.I and Q Nat. 3.7.I. See Griffin I992: 289-90. 
Pliny, in the fourteenth book of his Natural History, states that it was first bought 'in hisce XX annis' ('within the last 20 years') by Remmius Palaemon, and then sold by him 'intra decimum fere curae annum' ('within around ten years of its being in his care') to Seneca (I4.49-5I). In the same fourteenth book, Pliny says that ninety years have passed since the death of Virgil (I4.I8), which dates the book to 72 and hence Seneca's purchase to 62 - give or take a few years, as Pliny's numbers may be approximate, and even if they are not, the information at his disposal need not have been exact. This gives a range of c. 60-65 for De re rustica, or at least for Book $3 .{ }^{68}$ The work as a whole was published in instalments, and its composition may have extended over a few years. ${ }^{69}$

Another argument brings some further precision, specifically as regards the Book which concerns us most, the tenth. In the preface to that book Columella uses a striking metaphor:

Faenoris tui, Siluine, quod stipulanti spoponderam tibi, reliquam pensiunculam percipe: nam superioribus nouem libris hac minus parte debitum, quod nunc persoluo, reddideram.

Please receive, Silvinus, the remaining small instalment of the loan that on your stipulation I had pledged to pay you back: for in the preceding nine books I had already, minus the present portion, discharged the debt that I now settle.

The financial terminology here is strongly reminiscent of a conceit dominating the first three books of Seneca's Epistulae morales. There Seneca, at the end of each letter, introduces a quotation for Lucilius to ponder, and quite often jokingly presents this quotation as some kind of payment: a fee, a toll, an allowance, etc., but most often as the discharge of a debt. When in Ep. 29 he ends the practice (in Ep. 33 he will explain why), he writes, with the same jocularity as usual (29.10):

Si pudorem haberes, ultimam mihi pensionem remisisses; sed ne ego quidem me sordide geram in fine aeris alieni et tibi quod debeo inpingam.

If you had a sense of shame, you would have let me off the final instalment; but not even I will behave avariciously at the end of my debt, and I will thrust on you what I owe you.

Imitation, in one direction or the other, seems undeniable, and although it cannot be quite excluded that Seneca developed an idea he found in Columella, it is more likely that his elaborate deployment of the conceit is original, and that Columella is - to remain in the financial sphere - the borrower. This then would mean that the foreword to Book Io was not written earlier than the first three books of the Epistulae morales, which would give us a terminus post quem of early 63 or early $64 .^{70}$ In principle, the poem could have been written considerably earlier than the foreword, but Columella's language (10.pr.3-5) suggests that he had to be persuaded to compose Book ro in verse

\footnotetext{
68 This argument from Pliny was first developed by Becher I 897: IO. Columella generalises about the yield of Seneca's estate ('plerumque'), but this generalisation may be in part based on the yield under Palaemon, and need not imply that Seneca had been the owner for a longer period.

69 Quintilian claims that he wrote his twelve-book Institutio oratoria (747 pages OCT as against Columella's 552) in two years (ep. Tryph. I). On the publication in instalments of the Res Rustica, see Col. 2.I.I, 4.I.I, 5.I.I, Io.pr., I I.I.I-2 (but the reliability of Columella's statements is questioned by Henderson 2002). B.-J. Schröder I999: I Io believes that the table of contents that Columella added after Book I I was inspired by Plin., $H N$ I, which would give a terminus post quem for Book II of 76-77 (HN pr.3), but this seems impossibly late, and the idea of dependency on Pliny is not compelling.

${ }^{70}$ Ep. I 8 was written at the Saturnalia in December and Ep. 23 in early spring; the year is dependent on whether we accept the 'short' or the 'long' chronology of the Epistulae morales (see e.g. Griffin I992: 400, 518; Mazzoli I 989: I 850-3). We do not need to consider the date of publication, because Columella, as a member of Seneca's circle, may have known the texts beforehand.
} 
rather than to publish an existing poem as part of the De re rustica, and therefore it seems safest to take $c .63$ as a terminus post quem for those eclogues of Calpurnius that allude to the De cultu hortorum, i.e. I (at least the first lines), 2, 4 and possibly 5. Moreover, eclogue 4 also refers to the subject-matter of Book I I, written later than or perhaps concurrently with Book Io, and although such a reference is conceivable at an earlier date, when the book was only in the planning stage, it better fits a time when the work was either in progress or just finished (which would also explain why Calpurnius uses precisely the farmer's calendar, rather than other aspects of agriculture dealt with by Columella, as a synecdoche for De re rustica).

The dating I have arrived at, however, is considerably later than the dates that have hitherto been proposed by those who hold Calpurnius to be Neronian, as the first eclogue is uniformly placed by them very shortly after Nero's accession in October 54 and the fourth not much later, 55 being the favourite option. It is therefore necessary to look more closely into these dates.

\section{DATING CALPURNIUS}

To begin with the first eclogue, the arguments for dating it early in the reign of Nero were already marshalled by Sarpe in I8I9, and have never been questioned by those who hold Calpurnius to be Neronian. ${ }^{7 \mathrm{I}}$ The poem is concerned with the accession of the new emperor and his new political programme, and this was topical only so long as the accession was recent and the programme had just been announced. We find many close parallels with other programmatic texts that can be securely dated to the very first phase of Nero's reign: Nero's accession speech in the senate, written for him by Seneca, as reported by Tacitus (Ann. I3.4), and Seneca's own Apocolocyntosis and De clementia. Another indication of an early date is to be found in the much-discussed phrase, used of Nero, 'maternis causam qui uicit Iulis' ('who won the case for his maternal Julians', 45). Because of the perfect tense, this must refer to something that Nero has already done by the dramatic date of the poem, i.e. before his accession, and the most likely reference is to his successful speech in 53 on behalf of the Ilienses (the inhabitants of rebuilt Troy), in which, according to Tacitus (Ann. I 2.58.I), he expanded on the Trojan origin of the Romans and on Aeneas as the ancestor of the Julian family, to which Nero belonged through his mother Agrippina. ${ }^{72}$ But whatever the words may mean, they would be inappropriate after 59, when Agrippina was murdered on the orders of Nero, the official version being that she had committed suicide after having been discovered plotting against her son. ${ }^{73}$

However, an argument against a date earlier than 60 has been brought forward by Armstrong, who attempts to demonstrate that a passage in the first eclogue is dependent on the proem of Lucan's Bellum Ciuile. As that proem is in any case later than the Neronia of 60, and since Armstrong admits the argument from 'maternis ... Iulis', he concludes that Calpurnius cannot be Neronian at all. ${ }^{74}$ But both before and after his

\footnotetext{
71 Sarpe I 8I9: I4-27, tidied up by Haupt I 854: 2 I-4 $=$ I $875: 384-8$. For surveys of the literature since then, see Vinchesi 20I4: I 5-20, 28-9 and in the notes on the relevant passages.

72 Thus e.g. Vinchesi 20I4: I 28-30, with discussion of other views.

73 Tac., Ann. I4.Io; Suet., Nero 34.3; Dio Cass. 6I.I4.3. Of course, the words would still have been inappropriate upon publication, if that occurred, as I will argue, after 59; but failing to remove a phrase which had become offensive in the interim is surely easier to explain than introducing a phrase which was already offensive at the time of writing.

74 Armstrong I986: I26-8. For the date of Lucan's proem, see Suetonius' Life of Lucan: 'prima ingenii experimenta in Neronis laudibus dedit quinquennali certamine. Dein ciuile bellum ... recitauit' ('He gave the first demonstrations of his talent with a panegyric on Nero at the quinquennial [i.e. four-yearly] contest. Next,
} 
article, scholars have argued that the dependence is the other way around, ${ }^{75}$ and the matter deserves renewed investigation. In the passage in question, Faunus prophesies that the civil wars that have been ravaging the earth will cease as soon as the new emperor has established his reign $(46-5 \mathrm{I})$ :

Dum populos deus ipse reget, dabit impia uinctas
post tergum Bellona manus spoliataque telis
in sua uesanos torquebit uiscera morsus
et modo quae toto ciuilia distulit orbe,
secum bella geret; nullos iam Roma Philippos
deflebit, nullos ducet captiua triumphos.

As long as he, himself a god, will rule the peoples, impious Bellona will offer up her hands bound behind her back, and, stripped of her weapons, will twist her furious teeth against her own vitals, and the civil wars that recently she spread over the whole world, she will wage with herself; no more will Rome lament any Philippi again, no more will she conduct any triumphs when she herself is a captive.

Faunus' prophecy evokes a more famous one, that of Jupiter in the first book of Virgil's Aeneid, where it is 'Furor impius' rather than Bellona who is raging impotently, his hands bound behind his back (Aen. I.29I-6). ${ }^{76}$ Moreover, in the verse in sua uesanos torquebit uiscera morsus', Calpurnius incorporates another passage on civil war from the Aeneid: both the graphic 'uiscera' and the alliteration with $u$-recall Anchises' appeal to Caesar and Pompey in the Heldenschau: 'neu patriae ualidas in uiscera uertite uires' ('nor vent violent valour on the vitals of your land', Aen. 6.833). ${ }^{77}$ This verse is also imitated by Lucan at the very beginning of his Bellum Ciuile, where the poet announces that he will sing of civil war 'populumque potentem / in sua uictrici conuersum uiscera dextra' ('and a powerful people that has vented its victorious hand on its own vitals', 23), sharing with Calpurnius the line-beginning 'in sua u-' and the word 'uiscera' in the fifth foot. Lucan is closer to Virgil than Calpurnius, because he keeps the verb (con)uertere and, more importantly, because in his text the person(s) turning against their own vitals are Romans waging civil war rather than, as in Calpurnius, the personified abstraction of civil war. ${ }^{78}$ But it is conceivable that Lucan has disentangled the two Virgilian civil-war passages that Calpurnius had conflated and has restored the Virgilian conuertere in a kind of 'window-allusion'.

Another very close correspondence with the proem to the Bellum Ciuile is to be found in the reflections of both Calpurnius and Lucan on the problematic nature of the triumph in civil war. Calpurnius has Faunus prophesy that Rome will no longer bemoan civil war (for which Philippi is the emblem) and no longer hold triumphs while herself being a captive, whereas Lucan rhetorically asks the Romans why they chose to wage wars that could not have triumphs: 'bella geri placuit nullos habitura triumphos' (I.I2). Lucan articulates a

he recited the Bellum Cinile' (332.I-4 Hosius; a possible lacuna after dein does not affect the argument). For further evidence and discussion, see Fantham $20 \mathrm{II}$.

75 Most notably Narducci I979: 28-9 and Krautter I992: I90-5. Further literature in Vinchesi 20I4: I32 (who also favours Calpurnius' priority) and Karakasis 2016: 26-7 (who assumes Lucan's priority without argument).

76 This passage is also used by Lucan in his proem (I.60-2), but whereas Calpurnius imitates 294b-6, Lucan focuses on 29I-4a, so that there is no verbal overlap. See further Nauta 20I8: I 29-35.

77 Tr. Fairclough and Goold I999.

78 Calpurnius' 'torquebit' may be inspired by Sen., Oed. 962 'manus in ora torsit', of Oedipus' self-blinding, in fulfilment of the prophecy 'tecum bella geres' (237), which in its turn seems to be behind Calpurnius' 'secum bella geret' (noted as a parallel by Vinchesi 20I4: I32, together with HF 85 'bella iam secum gerat', which must be Seneca's original formulation of the thought). One of the anonymous referees points to Manil. $4.589-90$ 'uenti ... / erumpunt secumque gerent per inania bella'. For more on Manilius' presence in this passage of Calpurnius, see Nauta 202I, and for his presence in Lucan's proem Nauta 20I 8, as above, n. 76. 
topos in the discourse on civil wars, ${ }^{79}$ and Calpurnius' formulation has usually been understood to be a variation on that topos, but it may in fact have a different reference. To begin with, we need to understand which recent widespread civil war ('modo quae toto ciuilia distulit orbe / ... bella') he may have been thinking of. Already Sarpe pointed to the abortive rebellion led by Camillus Scribonianus in Dalmatia and Annius Vinicianus in Rome in 42, which was called a 'bellum ciuile' by Suetonius ( $\mathrm{Cl}$. I3); against this, Haupt argued that the reference must be more general, because Scribonianus' legions refused to move and the entire undertaking collapsed within five days; Wiseman, however, has demonstrated that the rebellion was a serious affair and could easily have developed into full-fledged civil war throughout the empire. ${ }^{80}$ Moreover, Cassius Dio presents the suppression of the revolt as the beginning of a long series of trials and condemnations, which saw high-born people held in prison and executed. ${ }^{8 \mathrm{I}}$ Dio's language here recalls that of Calpurnius in the passage quoted above ('captiua'), as well as a few lines further on, especially 'Nulla catenati feralis pompa senatus / carnificum lassabit opus, nec carcere pleno / infelix raros numerabit curia patres' ('No more will any funeral procession of chained senators weary the executioners at their task, nor will the unhappy Curia, the prison being full, count only infrequent Fathers', 60-2). It is this grim reality that makes Calpurnius speak of a peace only in appearance, a peace that in reality was closer to war, more particularly to civil war (54-9), ${ }^{82}$ so that only now, under the new ruler, have the civil wars really ended: 'nullos iam Roma Philippos / deflebit'.

Only two years after the abortive rebellion of Scribonianus, in 44 , Claudius celebrated an extravagant triumph for his subjection of Britain in $43 .{ }^{83}$ It is this triumph, I suggest, of which Calpurnius is thinking when he writes 'Roma ... / ... nullos ducet captiua triumphos': he would then mean that Rome will not again celebrate a triumph (over a foreign enemy, like all triumphs) at a time when many leading citizens are held captive, and are thus in the same position as the conquered enemies who are paraded in the procession. ${ }^{8}$ Suetonius remarks that in Claudius' triumph, the emperor was followed by those senators who had acquired the ornamenta triumphalia in the war (Cl. I7.3), and Dio says that this distinction was bestowed on all senators who had participated (60.23.2), but, as Wiseman points out, many of those thus honoured fell victim to the purges within a few years. ${ }^{85}$ The memory of a long train of senators marching in the pompa triumphalis must have jarringly contrasted with the image of a 'feralis pompa' of other, and even the same, senators being led to their execution, and this may well have prompted the thought 'Roma ... nullos ducet captiua triumphos'. Lucan would then have taken up this strikingly original formulation and adapted it to his own purposes. ${ }^{86}$

On the other hand, it may be argued that the entire theme of 'bella ... ciuilia' (Luc. I.I) 'ciuilia ... bella' (Calp. I.49-50) and the specific topic of the triumph in times of

\footnotetext{
79 See Havener 2015; Lange 2016: 95-I24.

80 Sarpe I 8I9: 39-40; Haupt I 854: $23=$ I $875: 387-8$ (referring to Suet., Cl. I3.2); Wiseman I982: 59-63. On the rebellion (called a 'bellum ciuile' also by Tac., Ann. I3.43.2), see further Osgood 20I I: 43-6.

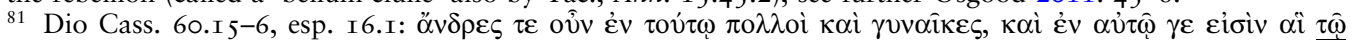

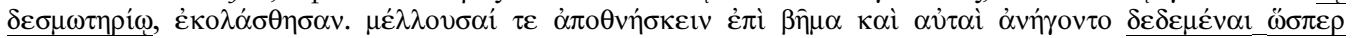

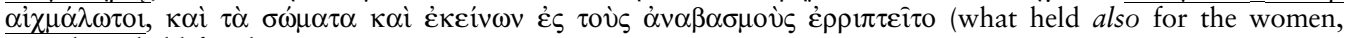
must have held for the men).

82 Similar thoughts on the pax of the Principate in Tac., Hist. I.50.2 (cf. I.2.I-3); Ann. I.I 0.4.

83 For the expedition to Britain and the triumph, see Osgood 20I I: 84-Io6.

84 Prisoners usually were held in the carcer not by way of punishment, but in preparation for trial or execution. Similarly, the most important of the captives paraded in the triumph faced execution at the end of the ceremony (even though it is unclear how often this was actually put into practice; see Beard 2007: I 28-32).

85 Wiseman I982: 65 .

${ }^{86}$ Lucan elsewhere also takes up the juxtaposition of feralis pompa and triumph: in 8.733 Cordus exclaims that the dead Pompey does not demand 'praeferat ut ueteres feralis pompa triumphos' (the phrase 'feralis pompa' is otherwise only attested in later prose).
} 
civil war are essential for Lucan in a way that they are not for Calpurnius, and that the latter's motivation for introducing this material may have come precisely from Lucan's proem. Whichever view one takes of the priority, problems for the dating of Calpurnius ensue. If Calpurnius is later than Lucan, the strong stress on the accession, the close correspondences with the texts of 54-55 and the 'maternis ... Iulis' are hard to account for. If Lucan is the imitator, a date of 54-55 for the first eclogue may be maintained, but we are left with the problem that the first three lines seem to be an allusion to the end of Columella's poem De cultu hortorum, which is not likely to be earlier than the $60{ }^{87}$

However, for this problem a solution may be proposed that has the added merit of also solving two other problems in the first eclogue. I have remarked above that Calpurnius' verses look like an homage to Columella's poem at the beginning of his book, and it is therefore natural to assume that they were added later, when the collection was put together. These three lines have long been suspect on quite unrelated grounds, because all other extant Latin eclogues from the classical period (Virgil, Calpurnius, the Einsiedeln Eclogues, Nemesianus) have a bucolic name in the first line, which in this eclogue appears only in the fourth: 'Cernis ut ecce pater quas tradidit, Ornyte, uaccae' ${ }^{88}$ It will not do to point to Virgil's eclogues on 'higher' subject-matter $(4,6$ and IO), where the first lines do not contain a herdsman's name, because they do have a proper noun or adjective connoting the bucolic genre ('Sicelides', 'Syracosio', 'Arethusa') ${ }^{89}$ If Calpurnius' first three lines were in fact a later addition, this would also solve the problem that the lines portray the vintage in late summer or early autumn, whereas the comet described in lines $77-83$ was visible in June and the beginning of July..$^{90}$ There is a similar contradiction with the final line of the eclogue, which assumes that the new emperor is already reigning: 'forsitan Augustas feret haec Meliboeus ad aures' ('perhaps Meliboeus will bring them [these songs] to the imperial ears', 94). This too could be a later addition, dedicating not only the poem, but the entire book to Columella: we have here both the mention of the name of the dedicatee (within the bucolic allegory) and the gift of the work with the request to hand it on to others, and thus to initiate what we may call 'publication' (i.e. wider circulation no longer controlled by the author)..$^{9 \mathrm{I}}$ If both the beginning and the end are later additions, the original eclogue would have had a consistent setting at the time of the comet - an obvious choice for the dramatic date of a prophecy of regime change. ${ }^{22}$ The additions

\footnotetext{
87 The lines are also reminiscent of Sen., Apoc. 2.I, but whereas Seneca describes the date of Claudius's death, Calpurnius of course points to an earlier date, because in his fiction the change of emperor is still in the future. Direct influence from the Apocolocyntosis is possible, but in view of the conventional nature of such high-flown periphrases of the time of year (which is precisely what Seneca makes fun of) not necessary. On Calpurnius' reception of the Apocolocyntosis, see further below, on eclogue 4 .

88 Hubaux I927. Hubaux notes (606) that the convention goes back to Theocritus (and ps.-Theocritus), even if Theocr. I has $\alpha i \pi$ ó $\lambda \varepsilon$ instead of a proper name (the goatherd never being named in the poem), 5 has the adjective $\Sigma v \beta \alpha \rho i \tau \alpha \nu$ (to go with $\Lambda \alpha \kappa \omega v \alpha$ in the second line), and I I is different because of the address to Nicias. Hubaux believed that Calp. I.I-3 was the end of a lost poem, but there can be no doubt that the book as we have it is complete, with eclogue 4 as the centre-piece (Korzeniewski I97I: 2; B. Schröder I99I: 9-I3).

89 The objection is in Vinchesi 20I4: IOO, with references to earlier literature.

90 Ramsey 2006: I36-40. On the problem of the chronological discrepancies in the eclogue, see Townend I980: I68, who explains them from 'poetical playing with dates' (accepted by Vinchesi 20I4: IOO).

91 On dedication and publication, see Nauta 2002: I20-3I. Strictly speaking, 'haec' refers to the prophecy of Faunus only, not to the entire poem or book, but such slippage is common in bucolic poetry: in the same way, a herdsman (Tityrus in Virgil, Corydon in Calpurnius), who speaks only a part of the text, may be construed, when identified with the poet, as the author of the text as a whole. Thus, Corydon asks Meliboeus at 4.52 'uis, hodierna tua subigatur pagina lima?', meaning the eclogue in which he is himself a character.

92 In the ancient sources, the comet is in retrospect seen as having presaged the death of Claudius, even though that occurred some four months later: Plin., HN 2.92; Suet., Cl. 46; Dio Cass. 60.35.I. For comets portending regime change, see Luc. I.529; Stat., Theb. I.708; Sil. 8.637; Tac., Ann. I4.22. I; Suet., Nero 36.I.
} 
would then have been made for the purpose of dedication to Columella when Calpurnius decided to put this poem in first position, because it was the earliest in dramatic (as well in factual) date and hence would make the most effective beginning of the small panegyrical cycle that was also to include the middle (fourth) and last (seventh) poem of the book.

The fourth eclogue is usually dated shortly after the first, mainly because the Golden Age is central to both. ${ }^{93}$ In the first eclogue Faunus predicts that the new emperor will bring back the Golden Age $(42-4,63-4)$, whereas the fourth eclogue opens with Corydon brooding about how to sing the 'aurea ... / saecula' (5-6) that have indeed now materialised. The answer is provided by Meliboeus in the ensuing dialogue: Corydon should imitate Virgil, of course, yet not the merely rustic eclogues, but specifically the fourth $(76-7)$, precisely the one in which the return of the Golden Age is announced. In the song-exchange that follows, Corydon ends with an appeal to the gods to recall the young emperor to the heavens only after a long life, but then caps this with a more extravagant request (I39-40):

\section{uel potius mortale resoluite pensum}

et date perpetuo caelestia fila metallo

or rather, loosen up the mortal stint and give celestial threads of eternal metal

The gods are addressed as if they were the Parcae, and asked to spin a new thread that is no longer mortal, i.e. finite, but celestial, and made of 'eternal metal', i.e. both unending and golden, signifying that the emperor's reign will be a perpetual Golden Age. The expression is so compressed as to verge on the obscure, but is clarified by a passage from Seneca's Apocolocyntosis, which is therefore likely to have been Calpurnius' model. ${ }^{94}$ There, Apollo describes what happens to the Parcae as they are spinning Nero's life-thread (4.I.57-60):

\section{Mirantur pensa sorores: \\ mutatur uilis pretioso lana metallo, aurea formoso descendunt saecula filo. \\ Nec modus est illis: felicia uellera ducunt et gaudent implere manus: sunt dulcia pensa.}

The sisters marvel at their stints: the cheap wool changes into precious metal, golden ages descend along the beautiful thread. And there is no end to them: they produce fleeces of happiness and rejoice to fill their hands: the stints are sweet.

Because the Apocolocyntosis was written in the very first months of the reign, it has generally been assumed that Calpurnius' lines belong to the same period. However, Champlin has argued that this part of Seneca's Menippean satire must be a later addition, because it features the identification of Nero with Apollo and his presentation as a singer, which cannot be paralleled before $59 .{ }^{95}$ But at whatever precise time the lines on the golden threads were written and at whatever precise time they were read by Calpurnius, there is no reason why he could not have imitated them in a poem dating from the early or mid 6os. From that period dates a telling remark by Seneca, made in the context of criticising the value put on gold: 'denique quod optimum uideri uolunt saeculum aureum appellant' ('finally, the age they want to be considered the best they

\footnotetext{
93 See Vinchesi 20I4: 29.

94 See B. Schröder I99I: I95-6.

95 Champlin 2003a: I I -35 and, specifically on the Apocolocyntosis, 2003 b. If Champlin is right about Apollo, Calp. 4 must be later than 59 for yet another reason than its dependence on Apoc. 4, because it refers to the emperor as 'Palatini ... Phoebi' (I 59; see above, Section III) and closely associates him with Apollo as inspiring deity (70-2, 87-9I).
} 
call the "Golden Age"', Ep. I I 5.I3). Seneca has just quoted Ovid's description of the golden palace and the golden chariot of the Sun (Met. 2.I-2, I07-8), and in view of the date of the letter (late 64), this cannot be read but as a dig against Nero's new Domus Aurea (as well as his chariot-racing and identification with the sun), and at the same time as a devastating comment on the ideology of the 'Golden Age'. ${ }^{66}$ Similarly potentially ambivalent displays of gold in this part of the reign were the 'Golden Day' (Dio Cass. 63.6.I) of the crowning of Tiridates in 66 and the celebration by orators and poets during the second Neronia of 65 of a gold-hoard allegedly found at Carthage (Tac., Ann. I6.I-3). ${ }^{97}$ Calpurnius may have positioned himself within this discourse, but for him as a bucolic poet, the main inspiration was, as we have seen Meliboeus point out to Corydon, Virgil's fourth eclogue, all the more so since Virgil himself had declared in the Aeneid (6.792-4) that the return of the Golden Age had come to pass under Augustus, i.e. the reigning emperor. ${ }^{98}$ Thus, even independently of what may or may not be the self-representation of a reign, it is the dynamics of the genre itself that prompts a bucolic poet to choose the theme of the Golden Age. ${ }^{99}$

The final (though not necessarily the last written) of the panegyrical eclogues is the seventh, which concludes the book. Unlike in the other two panegyrical eclogues, there is no mention of Meliboeus nor are there reflections of Columella's poetry (or prose), so that its dating is not affected by my argument about literary and personal dependency. The poem has Corydon report on a journey he has just made to Rome, where he visited a new wooden amphitheatre and watched a spectacle given there. This amphitheatre is mentioned by Tacitus under the year 57 (Ann. I3.3I.I), and also by Suetonius (Nero I2.I), who specifies that it was finished within a year. It is more likely that Tacitus' notice was prompted by the completion of the construction rather than its inception, and because we know of a naumachy in 57 (Dio Cass. 6I.9.5), it was probably in that year that the inaugural games were held, which is also the most likely occasion for Calpurnius' panegyric. ${ }^{\text {I00 }}$ His description of the spectacle itself provides no further clue, because it is very selective: he does not mention any gladiatorial fighting or wild-beast hunting, but concentrates, as befits his bucolic persona, on the strange animals on display, both terrestrial and aquatic - the latter may imply a naumachy, and in any case presuppose the technique of flooding the amphitheatre. ${ }^{\text {IOI }}$ The only possible

\footnotetext{
96 For the dating of Seneca's letters, see the references in n. 70 above. On this passage see Champlin 2003a: I 279. On the potentially ambivalent status of gold in a 'Golden Age' and the way this is exploited by various writers (Horace, Ovid, Seneca, Tacitus), see Feeney 2007: I 27-37 (Feeney there reads Calpurnius, after Horsfall I 997 , as a late antique Neronian impersonator, moved by 'a nostalgia for a lost historical age in which you could still feel a nostalgia for a lost mythical Golden Age', I37).

97 On these two episodes, see Champlin 2003a: I26-7; Champlin begins his discussion with the statement: 'The new era that dawned in 64 was a Golden Age', but it should be noted that, apart from Sen. Ep. I I 5 , the sources never speak of an age of gold.

98 Calp. I.64 'altera Saturni referet Latialia regna' imitates both Verg., Buc. 4.6 'redeunt Saturnia regna' and Aen. 6.792-4 'Augustus Caesar, diui genus, aurea condet / saecula qui rursus Latio regnata per arua / Saturno quondam'. The view that the Golden Age announced in the fourth eclogue was the reign of Augustus is also attested in Serv. and DServ. (Serv. ad 4.7: 'et hinc conicit fore aurea saecula, quod Augustus imperat'; see also (D)Serv. ad 4.6, I0, I2, I3, I 5, 20, 43) and elsewhere in the commentary tradition, and was surely already present in the commentaries of Calpurnius' time.

99 In later Latin bucolic we find this in Modoinus (Naso) under Charlemagne (edition in Korzeniewski I976) and very frequently in the Renaissance (see Grant I965: 33 I-4I).

100 I differ slightly from Vinchesi 20I4: 30-I, who reads Tacitus and Suetonius as pointing to 58. The identification of Calpurnius' amphitheatre as the Neronian one was one of the linchpins of the argumentation of Sarpe (I8I9: 28-34) and Haupt (I854: 22-3 = I 875:386-7), and proponents of a later date have put much effort into attempts to dislodge it: see Champlin I978: 96, I07; against this Townend I982: I69-73; yet again Champlin I986: I07-II, then Baldwin I995: I60-2, and finally Horsfall I997: I70-3, who posits a third-century poet who at least tried to describe the Neronian amphitheatre.

101 See Coleman I993: 56-7.
} 
obstacle to a date of 57 is the last line, in which Corydon says that the emperor, whom he has only seen from afar, looked like both Mars and Apollo. On the basis of Champlin's observation, mentioned above, that no public comparison or identification of Nero with Apollo can be found before 59, one could argue for 59 as the earliest possible date; in that case the spectacle could belong to the munus attested for that year (Tac., Ann. I4.I4.4). The amphitheatre, however, was still a striking novelty in the eyes of an old man who had long dwelled in the city $(43-4)$, so that a date later than 59 is unlikely.

These considerations would imply that eclogue 7 is earlier than eclogue 4 and the final version of eclogue I, both of which are to be dated, if my arguments are correct, to the early or mid-6os. The common assumption, however, is that eclogue 7 was the last of the panegyrical eclogues (and even of all eclogues in the book) to be written, and is to be read as Calpurnius' farewell to the bucolic genre. ${ }^{\text {IO2 }}$ Indeed, it strikingly reverses the bucolic values as set up in Virgil's first eclogue: there the herdsman, Tityrus, returns from the City of Rome, where he has met a 'iuuenis' also called a 'deus', who has enabled him to continue his bucolic existence, for which he promises eternal gratitude; here the herdsman, Corydon, likewise returning from Rome, enthusiastically describes the City's marvels, although he has seen the 'iuuenis deus' (6) only from afar, and he is perceptibly disappointed about having to resume his life in the country. ${ }^{\text {IO3 }}$ But this change in perspective has to do with the career of Virgil after the Bucolics: the great poet had gone on to write the Georgics and Aeneid, and this was conceived of as a movement from the country to the City; moreover, it was believed that it was Maecenas who had empowered the transition by his material support. ${ }^{\mathrm{IO} 4}$ One of the clearest instances of this scheme of thought is to be found in Calpurnius himself, at the end of the fourth eclogue, when Corydon addresses Meliboeus (4.I60-3):

Tu mihi talis eris, qualis qui dulce sonantem

Tityron e siluis dominam deduxit in urbem ostenditque deos et 'spreto', dixit, 'ouili,

Tityre, rura prius, sed post cantabimus arma.'

You will be for me such as he was, who led sweet-sounding Tityrus from the woods to the ruling city, showed him the gods, and said: 'We will scorn the sheepfold, Tityrus, and first sing of the countryside, but afterwards of arms.'

Here too, we have the ambition to leave the 'woods' for the City, and here too, but not in the seventh eclogue, we have the Maecenas-figure who may make it possible, and whom we have already met as a potential broker of access to the emperor in the first eclogue. The poet's as yet unfulfilled ambition is put at the end of the collection, whereas the fulfilment, or at least the promise of the fulfilment, together with grateful mention of the enabling patron, is put at the beginning, and this is precisely the structure of Virgil's Bucolics as they were read in Calpurnius' time. In the first eclogue, Tityrus, who was identified with Virgil, uttered his gratitude to the 'iuuenis' / 'deus', who was identified with Octavian, for regaining his lands, but in the ninth eclogue these lands were still lost, and Menalcas, who was there identified with Virgil, had not yet been able to

102 Cf. e.g. Hubbard I998: I75 'his last pastoral poem, a rejection of the pastoral life and vision'; Binder in Effe and Binder 200I: II3 'Abschied von der bukolischen Dichtung'; Vinchesi 20I4: 33 'la progressione (anche cronologica) delle ecloghe I, 4, 7'.

103 All this has often been elaborated; see Vinchesi 20I4: 477-80 for a survey and Karakasis 2016: 87, n. 3 for further bibliography.

104 The most important texts, apart from Calpurnius quoted below, are Laus Pisonis 230-5 and Mart. 8.55 (56), both mentioning Maecenas by name, as well as the alleged original beginning of the Aeneid as quoted in the Vita Suetoniana-Donatiana (42) and in the preface to Servius' commentary on the Aeneid (2.17-20 Thilo). 
recover them by the power of his poetry. ${ }^{\text {IO5 }}$ Thus in the life of Virgil as reconstructed from his Bucolics, the ninth eclogue came before the first, and similarly, I suggest, did Calpurnius expect his readers to reconstruct the biographical story behind his own book. ${ }^{\text {I06 }}$ The closural position of eclogue 7, the absence of Meliboeus, and the failure to meet the emperor, do not imply that 'Corydon' no longer has the support of Meliboeus, but that he has not yet acquired the patron to whom the book is dedicated in the first eclogue and whose benefits to the poet, both those enjoyed in the past and those requested for the future, are celebrated in the fourth. What became of the future benefits we cannot tell, because we have no information about Calpurnius and his relationship with his patron outside his book of Bucolics. But if that book is read with due attention to the surrounding Neronian literature, and above all to Columella, there is much that we can learn about the relationship of the poet to his patron. ${ }^{\text {IO }}$

\section{Faculty of Arts, University of Groningen}

r.r.nauta@rug.nl

\section{BIBLIOGRAPHY}

Armstrong, D. I986: 'Stylistics and the date of Calpurnius Siculus', Philologus I30, II 3-36.

Baldwin, B. I995: 'Better late than early: reflections on the date of Calpurnius Siculus', Illinois Classical Studies 20, I 57-67.

Barrett, A. A., Fantham, E. and Yardley, J. C. 2016: The Emperor Nero. A Guide to the Ancient Sources, Princeton/Oxford.

Bartalucci, A. 1976: 'Persio e i poeti bucolici di età neroniana', Rivista di cultura classica $e$ medioevale I 8, 85-1 I6.

Barthius, C. 16r3: Venatici et bucolici poetae latini, Hanover.

Beard, M. 2007: The Roman Triumph, Cambridge/London.

Becher, G. I897: De Lucii Junii Moderati Columellae vita et scriptis, Leipzig.

Becker, G. 20I2: Titus Calpurnius Siculus. Kommentar zur 5. und 6. Ekloge, Trier.

Beron, A.-E. 202 I: Calpurnius Siculus. Erste Ekloge, Stuttgart (announced; non uidi).

Birley, A. R. 2005: The Roman Government of Britain, Oxford.

Boldrer, F. I996: L. Iuni Moderati Columellae rei rusticae liber decimus (carmen de cultu hortorum), Pisa.

Boldrer, F. 2000: 'Tra mosto e Falerno: una "lectio media” in Columella ro.43 I', Lexis I 8, 243-54.

Burmannus, P. I73 I: Poetae latini minores, vol. I, Leiden.

Camodeca, G. I986: 'I consoli del 55-56 e un nuovo collega di Seneca nel consolato: P. Cornelius Dolabella (TP. 75 [= I40] + I35', Zeitschrift für Papyrologie und Epigraphik 63, 20I-I 5.

Castagna, L. I976: I bucolici latini minori. Una ricerca di critica testuale, Florence.

Champlin, E. I978: 'The life and times of Calpurnius Siculus', Journal of Roman Studies 68, 95-I Io.

Champlin, E. I986: 'History and the date of Calpurnius Siculus', Philologus I30, I04-I2.

Champlin, E. 2003a: Nero, Cambridge/London.

Champlin, E. 2003 b: 'Nero, Apollo and the poets', Phoenix 57 (2003), 276-83.

Chytil, F. I 893-4: Der Eklogendichter T. Calpurnius Siculus und seine Vorbilder, Znaim (Znojmo).

Cichorius, C. I922: Römische Studien, Leipzig/Berlin.

Coleman, K. M. I993: 'Launching into history: aquatic displays in the early Empire', Journal of Roman Studies 83, 48-73.

105 On this way of reading, to be reconstructed from first-century texts (such as Quint., Inst. 8.6.46-7 and Mart. $8.55(56))$ as well as from the ancient commentaries, see Nauta 2006: 302-5. More in general on Calpurnius' use of Virgilian allegoresis: Langholf 1990.

106 The innovative political contents, as yet unsuccessful in gaining the poet the wished-for patronage, of Calp. 7 parallel those in Verg., Buc. 9, and both eclogues encode the traditional bucolic world as 'ueteres (...) fagos' (Calp. 7.5; Verg., Buc. 9.9), the fagus being the tree characteristic of the bucolic genre (Verg., Buc. I.I $\approx$ G. 4.566).

107 Another relevant work of Neronian literature (as I think, in spite of Stover 201 5) are the Einsiedeln Eclogues, which may also be connected to Columella and his environment. This I will discuss in a separate article. 
Courtney, E. 1987: 'Imitation, chronologie littéraire et Calpurnius Siculus', Revue des Études Latines $65, \mathrm{I} 48-57$.

Di Brazzano, S. 2004: Laus Pisonis, Pisa.

Di Salvo, L. I990: T. Calpurnio Siculo. Ecloga VII, Bologna.

Drinkwater, J. F. 2019: Nero. Emperor and Court, Cambridge.

Effe, B. and Binder, G. 200I: Antike Hirtendichtung. Eine Einführung, 2nd edn, Düsseldorf/Zürich.

Fairclough, H. R. and Goold, G. P. I999: Virgil. Eclogues. Georgics. Aeneid I-VI, Cambridge/ London.

Fantham, E. 20I I: 'A controversial life', in P. Asso (ed.), Brill's Companion to Lucan, Leiden/Boston, 3-20.

Fantuzzi, M. and Papanghelis, T. (eds) 2006: Brill's Companion to Greek and Latin Pastoral, Leiden/ Boston.

Feeney, D. 2007: Caesar's Calendar. Ancient Time and the Beginnings of History, Berkeley, CA.

Fey-Wickert, B. 2002: Calpurnius Siculus. Kommentar zur 2. und 3. Ekloge, Trier.

Fucecchi, M. 2009: 'Ovidio e la nuova bucolica di Calpurnio: osservazioni e proposte', in L. Landolfi and R. Oddo (eds), Fer propius tua lumina. Giochi intertestuali nella poesia di Calpurnio Siculo, Bologna, 4I-65.

Glaeser, C. E. I842: T. Calpurnii Siculi Eclogae, Göttingen.

Grant, W. L. I965: Neo-Latin Literature and the Pastoral, Chapel Hill, NC.

Griffin, M. T. I992: Seneca. A Philosopher in Politics, 2nd edn, Oxford.

Hall, J. B. I969: Claudian: De raptu Proserpinae, Cambridge.

Hartenberger, R. I9I I: De o finali apud poetas latinos ab Ennio usque ad Iuvenalem, Bonn.

Haupt, M. I 854: De carminibus bucolicis Calpurnii et Nemesiani, Berlin.

Haupt, M. I 875: Opuscula, vol. I, Leipzig.

Havener, W. 2015: 'Triumphus ex bello civili? Die Präsentation des Bürgerkriegssieges im spätrepublikanischen Triumphritual', in H. Börm, M. Mattheis and J. Wienand (eds), Civil War in Ancient Greece and Rome. Contexts of Disintegration and Reintegration, Stuttgart, I $49-84$.

Havercamp, S. and Bruce, R. I728: Poetae latini. Rei venaticae scriptores et bucolici antiqui, Leiden.

Henderson, J. 2002: 'Columella's living hedge: the Roman gardening book', Journal of Roman Studies 92, I IO-33.

Henderson, J. 2013: 'The Carmina Einsidlensia and Calpurnius Siculus' Eclogues', in E. Buckley and M. Dinter (eds), A Companion to the Neronian Age, Chichester, I70-87.

Hine, H. M. 2006: 'Rome, the cosmos, and the emperor in Seneca's Natural Questions', Journal of Roman Studies 96, 42-72.

Horsfall, N. I993: 'Cleaning up Calpurnius', Classical Review 43, 267-70.

Horsfall, N. I997: 'Criteria for the dating of Calpurnius Siculus', Rivista di filologia e di istruzione classica I25, I66-96.

Hubaux, J. I 927: 'Le vers initial des éclogues. Contribution à l'histoire du texte des bucoliques latins', Revue belge de philologie 6, 603-16.

Hubbard, T. K. I998: The Pipes of Pan. Intertextuality and Literary Filiation in the Pastoral Tradition from Theocritus to Milton, Ann Arbor, MI.

Karakasis, E. 20ı 6: T. Calpurnius Siculus. A Pastoral Poet in Neronian Rome, Berlin/Boston.

Kettemann, R. 1977: Bukolik und Georgik. Studien zu ibrer Affinität bei Vergil und später, Heidelberg.

Korzeniewski, D. I97I: Hirtengedichte aus neronischer Zeit, Darmstadt.

Korzeniewski, D. I976: Hirtengedichte aus spätrömischer und karolingischer Zeit, Darmstadt.

Krautter, K. I992: 'Lucan, Calpurnius Siculus und Nero', Philologus I36, I88-20I.

Lange, C. H. 2016: Triumphs in the Age of Civil War. The Late Republic and the Adaptability of Triumphal Tradition, London.

Langholf, V. I990: 'Vergil-Allegorese in den Bucolica des Calpurnius Siculus', Rheinisches Museum für Philologie I33, 350-70.

Lehoux, D. 2007: Astronomy, Weather, and Calendars in the Ancient World. Parapegmata and Related Texts in Classical and Near-Eastern Societies, Cambridge.

Littlewood, C. 20I7: 'Post-Augustan revisionism', in S. Bartsch, K. Freudenburg and C. Littlewood (eds), The Cambridge Companion to the Age of Nero, Cambridge, 79-92.

Lowe, D. 20I0: 'The symbolic value of grafting in ancient Rome', Transactions of the American Philological Association I40, 46I-88. 
Mayer, R. I980: 'Calpurnius Siculus: technique and date', Journal of Roman Studies 70, I75-6.

Mayer, R. 2006: 'Latin pastoral after Virgil', in Fantuzzi and Papanghelis 2006, 45 I-66.

Mazzoli, G. 1989: 'Le “Epistulae Morales ad Lucilium” di Seneca. Valore letterario e filosofico', Aufstieg und Niedergang der römischen Welt 2.36.3, I 823-77.

Mynors, R. A. B. I990: Virgil: Georgics, Oxford.

Narducci, E. I979: La provvidenza crudele. Lucano e la distruzione dei miti augustei, Pisa.

Nauta, R. R. 2002: Poetry for Patrons. Literary Communication in the Age of Domitian, Leiden etc.

Nauta, R. R. 2006: 'Panegyric in Virgil's Bucolics', in Fantuzzi and Papanghelis 2006, 30I-32.

Nauta, R. R. 20г8: “'Zweimal Emathien”: Das Proöm zu Lucans Bellum Ciuile und die Georgica Vergils', in S. Finkmann, A. Behrendt and A. Walter (eds), Antike Erzähl- und Deutungsmuster. Zwischen Exemplarität und Transformation (FS C. Reitz), Berlin/Boston, I 2 I-44.

Nauta, R. R. 202I: 'Calpurnius Siculus in the Flavian poets', in M. Heerink and E. Meijer (eds), Flavian Responses to Neronian Rome, Amsterdam (forthcoming).

Osgood, J. 20I I: Claudius Caesar. Image and Power in the Early Roman Empire, Cambridge.

Prioux, É. 20I 3: 'Columelle et le genus floridum : images programmatiques et parodie dans le livre X du De Re rustica', Dictynna Io (https://doi.org/I0.4000/dictynna.959).

Ramsey, J. T. 2006: A Descriptive Catalogue of Greco-Roman Comets from 500 B.C. to A.D. 40o, Syllecta Classica I7, Iowa City.

Reeve, M. D. I978: 'The textual tradition of Calpurnius and Nemesianus', Classical Quarterly 78, $223-38$.

Reitz, C. 2006: Die Literatur im Zeitalter Neros, Darmstadt.

Rodgers, R. H. 2010: L. Iunii Moderati Columellae Res Rustica. Incerti auctoris Liber de arboribus, Oxford.

Sarpe, G. I8I9: Quaestiones philologicae, Rostock.

Schröder, B. I991: Carmina non quae nemorale resultent. Ein Kommentar zur 4. Ekloge des Calpurnius Siculus, Frankfurt.

Schröder, B.-J. I999: Titel und Text. Zur Entwicklung lateinischer Gedichtüberschriften. Mit Untersuchungen $z u$ lateinischen Buchtiteln, Inhaltsverzeichnissen und anderen Gliederungsmitteln, Berlin/New York.

Sider, D. and Brunschön, C. W. 2007: Theophrastus of Eresus: On Weather Signs, Leiden/Boston.

Stover, J. 201 5: 'Olybrius and the Einsiedeln Eclogues', Journal of Roman Studies I05, 288-32 I.

Titius, R. I590: M. Aurelii Olympii Nemesiani Carthaginiensis. T. Calphurnii Siculi Bucolica, Florence.

Townend, G. B. I980: 'Calpurnius Siculus and the munus Neronis', Journal of Roman Studies 70, I 66-74.

Vinchesi, M. A. 2014: Calpurnii Siculi Eclogae, Florence.

Vlitius, J. I645: Venatio novantiqua, Leiden.

Wernsdorf, J. C. I780: Poetae latini minores, vol. 2, Altenburg.

Wiseman, T. P. I982: 'Calpurnius Siculus and the Claudian civil war', Journal of Roman Studies 72, 57-67.

Wiseman, T. P. 2013: 'The Palatine, from Evander to Elagabalus', Journal of Roman Studies го3, 234-68.

Wiseman, T. P. 2019: The House of Augustus. A Historical Detective Story, Princeton/Oxford. 